\title{
Two new mesophilous oriental hornbeam communities from the northern Dinaric Alps (Bosnia and Herzegovina)
}

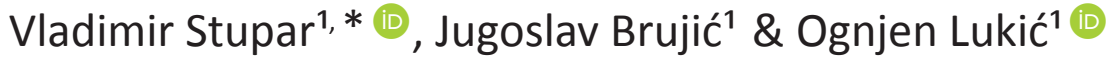

Key words: Carpinus orientalis, Carpinion orientalis, Ostryo-Tilion, Erythronio-Carpinion, Epimedio alpini-Carpinetum orientalis, Asplenio scolopendrii-Carpinetum orientalis, phytosociology, syndynamics.

Ključne besede: Carpinus orientalis, Carpinion orientalis, OstryoTilion, Erythronio-Carpinion, Epimedio alpini-Carpinetum orientalis, Asplenio scolopendriiCarpinetum orientalis, fitocenologija, sindinamika.

Received: 1. 5. 2020

Revision received: 18.5 .2020

Accepted: 6. 6. 2020

\begin{abstract}
The paper describes two new mesophilous communities of oriental hornbeam (Carpinus orientalis) coppice from the northern Dinaric Alps in Bosnia and Herzegovina $(\mathrm{B} \& \mathrm{H})$. While oriental hornbeam is mainly considered to be a part of thermophilous forests and scrub, numerical analysis of 103 relevés of C. orientalis dominated coppice from $\mathrm{B} \& \mathrm{H}$ has shown that two new, rather mesophilous, communities thrive on calcareous bedrock of NW B\&H. They represent secondary successional stages of mesotermic forest vegetation in this region. Association Epimedio alpini-Carpinetum orientalis ass. nova hoc loco is related to Illyrian oak-hornbeam forests of Erythronio-Carpinion betuli, while Asplenio scolopendrii-Carpinetum orientalis ass. nova hoc loco is linked to Balkan submediterranean ravine forests of Ostryo-Tilion. Although these two associations were recorded only in the NW $\mathrm{B} \& \mathrm{H}$, their distribution is potentially larger, as their source communities are relatively common throughout the Dinaric Alps, so the information about their distribution, vertical structure, and syndynamic relations could be very useful in a national scale forest management and nature conservation.
\end{abstract}

Izvleček

V članku opisujemo dve novi panjevski mezofilni združbi kraškega gabra (Carpinus orientalis) v severnem delu Dinarskega gorstva v Bosni in Hercegovini $(\mathrm{B} \& \mathrm{H})$. Kraški gaber gradi predvsem termofilne gozdove in grmišča, vendar je numerična amaliza 103 popisov panjevcev s prevladujočim kraškim gabrom $\mathrm{v}$ $\mathrm{B} \& \mathrm{H}$ pokazala, da dve novi mezofilni združbi uspevata na apnenčasti podlagi $\mathrm{v}$ severozahodni B\&H. Predstavljata faze v sekundarni sukcesiji mezotermne gozdne vegetacije v tem območju. Asociacija Epimedio alpini-Carpinetum orientalis ass. nova hoc loco je povezana z ilirskimi hrastovo-gabrovimi gozdovi zveze ErythronioCarpinion betuli, asociacija Asplenio scolopendrii-Carpinetum orientalis ass. nova hoc loco pa z balkanskimi submediteranskimi gozdovi plemenitih listavcev zveze Ostryo-Tilion. Čeprav sta ti dve asociaciji zabeleženi samo v severozahodnem delu $\mathrm{B} \& \mathrm{H}$ je njihova potencialna razširjenost večja, saj so njihove izvorne združbe relativno pogoste v celotnem Dinarskem gorstvu. Zato je poznavanje njihove razširjenosti, vertikalne strukture in sindinamskih odnosov uporabno za gospodarjenje z gozdom in naravovarstvo na nacionalnem nivoju. 


\section{Introduction}

Oriental hornbeam (Carpinus orientalis) is a thermophilous and xerophilous tree species distributed in SE Europe (southern Italy and Balkan Peninsula) and extending to the Asia Minor, Syria, Caucasus region and Crimea (Sikkema \& Caudullo 2016). Being typical element of Submediterranean forest vegetation, it can also be found on warmer sites of continental regions of its area of distribution. It is main species of canopy layer in Submediterranean thermophilous oriental-hornbeam forests of the Central and Southern Balkans (Syringo-Carpinion orientalis) (Mucina et al. 2016) and important understory species of many thermophilous deciduous oak-dominated forest communities of Carpinion orientalis and Quercion frainetto (Blasi et al. 2001, Vukelić 2012, Tomić \& Rakonjac 2013, Stupar et al. 2016, Tzonev et al. 2019). The latter communities are often structurally degraded to Carpinus orientalis dominated coppice. Although floristically they can be very different, such degraded oriental hornbeam communities mainly have closed or semi-open canopy and, being mainly coppice, all of them share common prominent synmorphological characteristic, such as bushy appearance (related to the fact that after the cut back of the oriental hornbeam trees several shoots develop simultaneously from one stool).

Regardless of floristic differences, this physiognomical similarity led to poor recognition of new vegetation types within oriental hornbeam coppices in Western Balkans, as was already brought to attention by Šugar \& Trinajstić (1988) who distinguished continental C. orientalis coppice in Croatia (Cruciato glabrae-Carpinetum orientalis) from Mediterranean Querco-Carpinetum orientalis. Majority of other continental $C$. orientalis coppices in the Western Balkans were treated in the scope of one widely comprehended association known under several invalid or illegitimate names (Stefanović 1989, Stupar et al. 2015). Moreover, until recently, there were only a few associations of $C$. orientalis dominated coppice recognized and correctly described in the whole Balkan Peninsula (Blečić \& Lakušić 1967, Šugar \& Trinajstić 1988, Bergmeier \& Dimopoulos 2008, Tzonev 2013).

However, recent research suggests that there is a much higher diversity among these communities since they appear in different regions, reflect different ecological conditions, and are degradations of different types of oak forests (i.e., those of Carpinion orientalis, Quercion confertae or Erythronio-Carpinion) (Stupar et al. 2015, Miletić et al. 2016). While Stupar et al. (2015) encompassed all of the continental communities in Bosnia and Herzegovina
$(\mathrm{B} \& \mathrm{H})$ under the association Cruciato glabrae-Carpinetum orientalis Šugar et Trinajstić ex Stupar et al. 2015, they stated that this association is rather heterogeneous, with mesophilous species playing an important role in some stands in the NW B\&H, and that further research is needed to reveal its diversity patterns. Additionally, they pointed out that in this transitional zone between Central and SE Europe, within the association of Aceri obtusati-Quercetum petraeae Stupar et al. 2015 one can find together two species of different ecologies, mesophilous Carpinus betulus, and xerothermophilous Carpinus orientalis. This suggested that there are possibly some more mesophilous communities where $C$. orientalis plays an important role in $\mathrm{B} \& \mathrm{H}$.

The study aimed to use the results of the recent field research of $C$. orientalis coppice in $\mathrm{B} \& \mathrm{H}$ to describe two new mesophilous communities dominated by oriental hornbeam and characterize them by their ecology and floristic composition, which would in turn aid to the classification of this vegetation type in $\mathrm{B} \& \mathrm{H}$, as well as in the wider context.

\section{Methods and materials}

\section{Study area}

The research took place in the middle part of the Vrbas River canyon with its surroundings. The area is situated in northwestern $\mathrm{B} \& \mathrm{H}$ and it is about a $40 \mathrm{~km}$ long geomorphological feature that predominantly has southnorth direction in the northern part of the Dinaric Alps (Figure 1). Limestone canyons and gorges are intersected by a few rather small valleys in Bočac, Krupa na Vrbasu, Rekavice, and Karanovac and surrounded by predominantly limestone and dolomitic low mountains (up to $1330 \mathrm{~m}$ a.s.l.) and plateaus (400-600 m a.s.l) Čemernica, Tisovac, Osmača and Starčevica to the east and Manjača Mt. to the west (Mojićević et al. 1976, Marinković \& Ahac 1979). Vrbas River elevations are between $160 \mathrm{~m}$ in the north and $270 \mathrm{~m}$ a.s.l. in the south. Climate is modified continental with the maritime influence from the west and Mediterranean from the south (Delijanić et al. 1964). The average annual temperature for Banja Luka is $11.0^{\circ} \mathrm{C}$ and annual rainfall is $1024 \mathrm{~mm}$ (Anonymous n.d.). Biogeographically, this area lies at the border between two regions, i.e., Pre-Pannonian (continental, northern $\mathrm{B} \& \mathrm{H}$ ) and Dinaric (mountainous, central B\&H) (Stefanović et al. 1983). It is also an area that is under the strong anthropogenic influence for centuries, and large portions of land were either deforested or structurally degraded to coppice or shrub communities. 


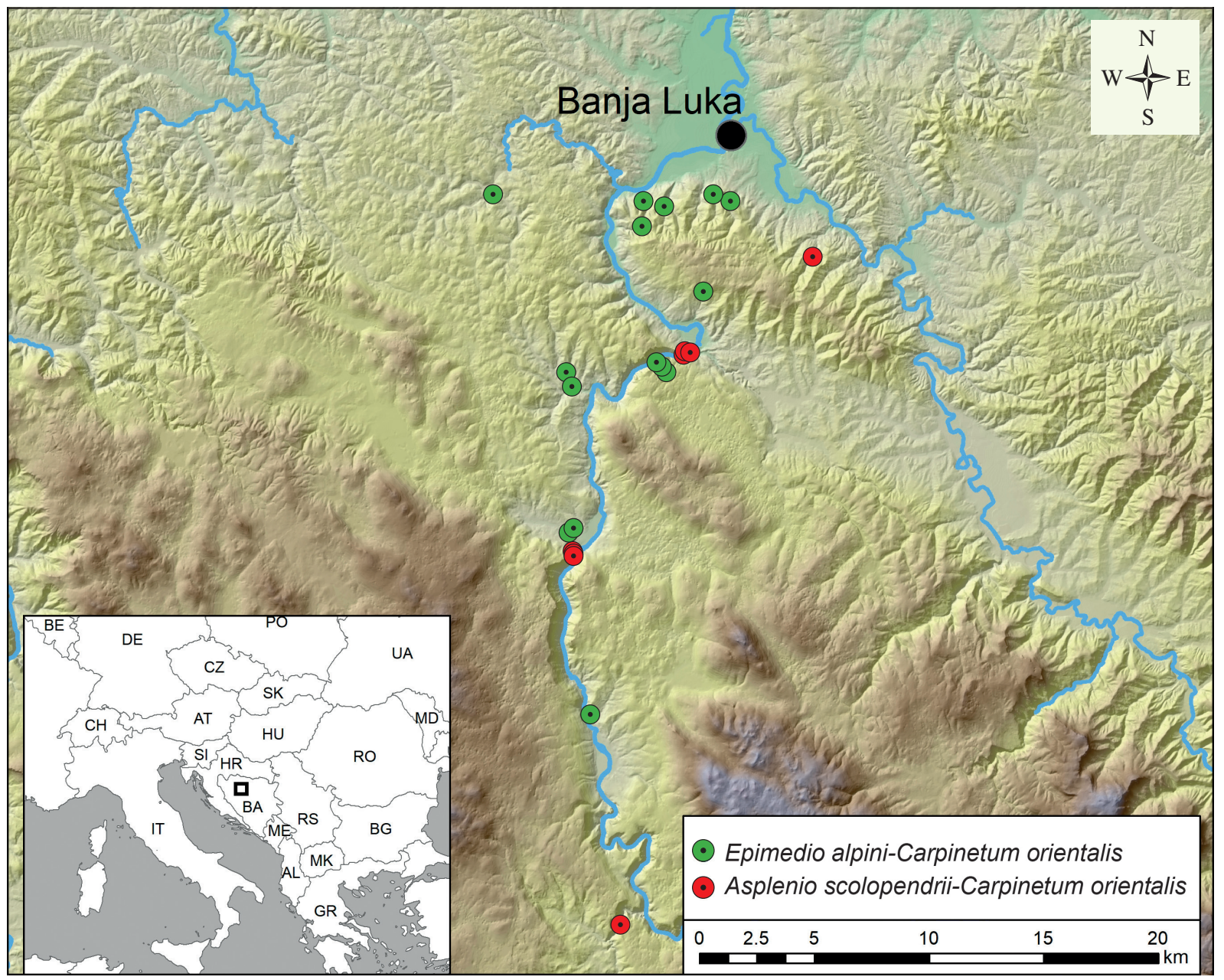

Figure 1: Locations of relevés.

Slika 1: Lokacije popisov.

\section{Data collection and analysis}

All 103 relevés used in this study are stored in, and available from, the Forests Vegetation Database of Bosnia and Herzegovina, with the ID EU-BA-001 in the Global Index of Vegetation-Plot Databases (Dengler et al. 2011). From the year of 1998, but mainly in the last ten years, we recorded 51 relevés of $C$. orientalis coppice in $\mathrm{B} \& \mathrm{H}$ using standard Central European phytosociological method (Braun-Blanquet 1964). Together with 52 relevés from literature (Fabijanić et al. 1963, Stefanović \& Manuševa 1971, Kaćanski 1983, Stefanović 1989, Lakušić \& Redžić 1991, Muratspahić et al. 1991, Bucalo 1999, Miletić et al. 2016) they were stored into the Turboveg database (Hennekens \& Schaminée 2001) and then exported into JUICE software (Tichý 2002) for further analysis.

Before numerical analysis was applied, we excluded mosses from the dataset, as they were not recorded by all authors. For the means of numerical analysis, all layers were merged into a single layer to take account of inconsistent sampling in the relevés from literature, even though we recorded four layers during the field investigation (canopy layer: $<10$ and $>5 \mathrm{~m}$, understory layer: $<5$ and $>1 \mathrm{~m}$, shrub layer: $<1 \mathrm{~m}$ and herb layer). However, understory and shrub layers were combined into a single understory layer for use in the text and the preparation of the tables with relevés. Records of species determined to the genus level were deleted. Taxa occurring in three or fewer relevés were omitted from the analysis to reduce noise (Juvan et al. 2013, Stupar et al. 2015). Quercus daleschampi was treated as $Q$. petraea, while Lathyrus vernus and L. venetus were combined. Taxa from taxonomically critical groups were also combined (Bromus erectus, Carex muricata, Cytisus hirsutus, Festuca pseudovina, and Taraxacum officinale). 
The numerical classification of the data set was performed in PC-ORD (McCune \& Mefford 1999) using Flexible beta $(-0.25)$ and Relative Sørensen. Considering that the study aimed to delineate and describe mesophytic oriental hornbeam communities outside of Carpinion orientalis, after cluster analysis, we selected the level of division (four groups of relevés) that best suited the aim. Diagnostic species for clusters were determined using species fidelity measure (Chytrý et al. 2002) in the JUICE software. We also calculated Fischer's exact test and gave a zero fidelity value to a species with $\mathrm{P}>0.001$. The threshold phi value for the species to be considered as a diagnostic was set at 0.25 .

All relevés, together with the unweighted species ecological indicator values (EIVs) for temperature, light, moisture, continentality, soil reaction and nutrients (Pignatti et al. 2005) were passively projected onto a nonmetric multidimensional scaling (NMDS) plot to relieve main ecological factors that affect the variation of the floristic composition inside the data set. We used BrayCurtis distance measure and square-root transformation of cover data. The significance of EIVs correlation with the NMDS relevé scores was tested using the modified permutation test proposed by Zelený \& Schaffers (2012). The analysis was done in $\mathrm{R}$ software, version 3.4.1 (The R Foundation for Statistical Computing 2017) using the vegan package (https://github.com/vegandevs/vegan).

Plant nomenclature followed Euro+Med (2006). Syntaxonomical concepts and nomenclature of higher syntaxa followed Mucina et al. (2016). Descriptions of new syntaxa strictly followed the rules of ICPN (Theurillat et al. 2020).

\section{Results}

Numerical analysis of Carpinus orientalis dominated coppice from Bosnia and Herzegovina led to the delimitation of four ecologically and floristically distinct groups of clusters (Figure 2): xerophilous (clusters 1 and 2) and mesophilous (clusters 3 and 4). They are characterized by distinctive floristic composition with clearly defined diagnostic species (Table 1). This is also supported by the NDMS ordination plot, where the main ecological factors influencing the variation in the floristic composition are moisture and nutrients (positively correlated to the first axis) and light (negatively correlated to the first axis) (Figure 3). Xerophilous clusters (left side of the ordination and cluster diagrams) belong to already known associations, i.e., Rusco aculeati-Carpinetum orientalis Blečić et Lakušić 1967 (cluster 1) and Cruciato glabrae-Carpinetum orientalis Šugar et Trinajstić ex Stupar et al. 2015

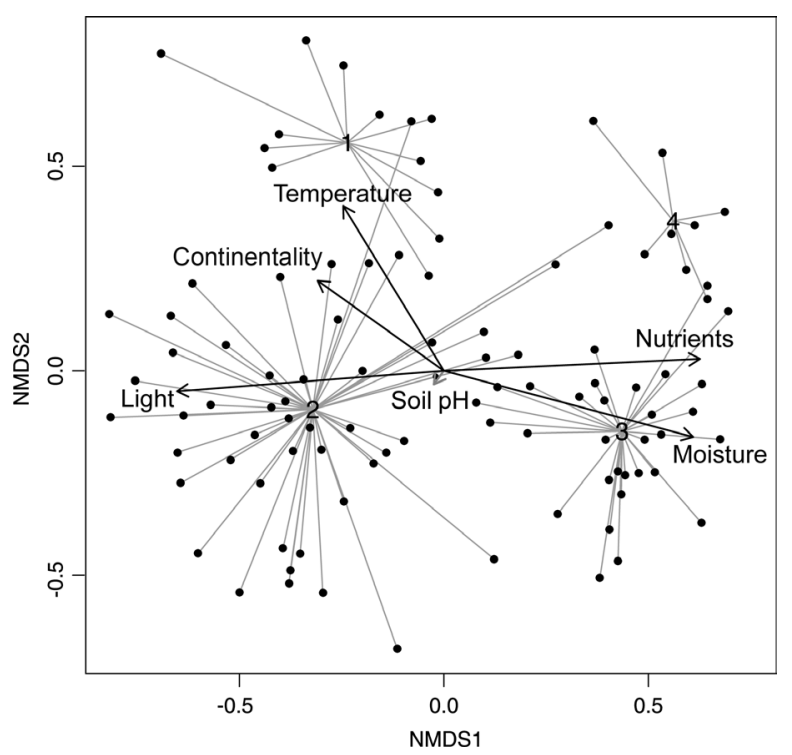

Figure 3: NDMS spider plot of 103 classified relevés of the C. orientalis coppice in $\mathrm{B} \& \mathrm{H}$ with EIVs passively projected. Centroids of clusters are indicated by numbers corresponding to Table 1, Figure 2, and to cluster numbers used in the text.

Slika 3: NDMS graf 103 klasificiranih popisov panjevcev kraškega gabra v B\&H s pasivno projiciranimi EIV vrednostmi. Centroidi klastrov so predstavljeni s številkami, ki odgovarjajo klastrom v Tabeli 1, Sliki 2 in številkam klastrov v besedilu.

Figure 2: Classification of $C$. orientalis coppice in Bosnia and Herzegovina. Clusters:

1 - Rusco aculeati-Carpinetum orientalis,

2 - Cruciato glabrae-Carpinetum orientalis,

3 - Epimedio alpini-Carpinetum orientalis,

4 -Asplenio scolopendrii-Carpinetum orientalis.

Slika 2: Klasifikacija panjevcev kraškega gabra $v$ Bosni in Hercegovini. Klastri:

1 - Rusco aculeati-Carpinetum orientalis,

2 - Cruciato glabrae-Carpinetum orientalis,

3 - Epimedio alpini-Carpinetum orientalis,

4 -Asplenio scolopendri-Carpinetum orientalis.

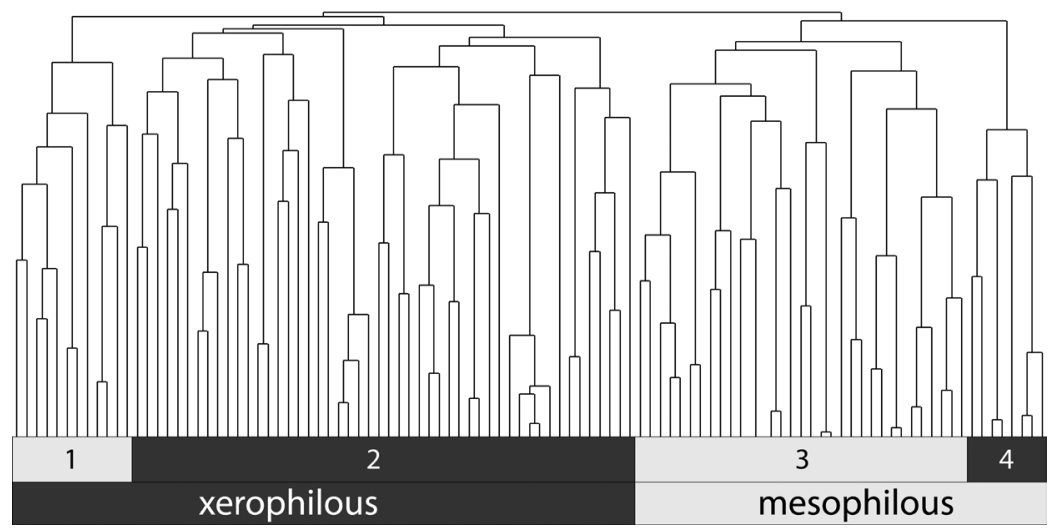


(cluster 2), while mesophilous clusters 3 and 4 (right side of the ordination and cluster diagrams) are recognized as new associations.

These results suggest new syntaxonomical scheme of Carpinus orientalis coppice in $\mathrm{B} \& \mathrm{H}$ with four associations within three alliances and two classes:

Quercetea pubescentis Doing-Kraft ex Scamoni et Passarge 1959

Quercetalia pubescenti-petraeae Klika 1933

Carpinion orientalis Horvat 1958

Rusco aculeati-Carpinetum orientalis Blečić et Lakušić 1967

Cruciato glabrae-Carpinetum orientalis Šugar et Trinajstić ex Stupar et al. 2015

Carpino-Fagetea sylvaticae Jakucs ex Passarge 1968

Carpinetalia betuli P. Fukarek 1968

Erythronio-Carpinion (Horvat 1958) Marinček

in Wallnöfer et al. 1993

Epimedio alpini-Carpinetum orientalis ass. nova hoc loco (Table 1 column 3, Table 2)

Aceretalia pseudoplatani Moor 1976 nom. conserv. propos.

Ostryo carpinifoliae-Tilion platyphylli (Košir et al.

2008) Čarni in Willner et al. 2016

Asplenio scolopendrii-Carpinetum orientalis ass. nova hoc loco (Table 1 column 4, Table 3)

\section{Description of the new syntaxa}

\section{Epimedio alpini-Carpinetum orientalis ass. nova hoc loco (Table 1, column 3)}

Typus: Table 2, rel. 11 - holotypus hoc loco

Stands of this association are coppices that represent secondary succession stages of the association Aceri obtusati-Quercetum petraeae Stupar et al. 2015. They are found in NW BIH (Figure 1), on mild to moderately steep mainly warmer slopes on calcareous substrates (limestone and dolomites) and elevations between 200 and $600 \mathrm{~m}$ a.s.l. Due to closed canopy, the stands are very shaded which results in the poorer species composition than the source association, however, the cover of the herb layer can sometimes be very high. These stands are coppices with a bushy appearance and height between 5 and 10 $\mathrm{m}$ (Figure 4). Due to mild terrain relief and closeness to settlements, these stands are continuously being coppiced and consequently maintained in the degraded stage.

The dominant species of the canopy layer is Carpinus orientalis, while other diagnostic species include species characteristic for oak-hornbeam forests (Erythronio-Carpinion betuli) such as Carpinus betulus, Cyclamen purpurascens, Epimedium alpinum, Helleborus odorus, Potentilla micrantha, Primula acaulis, Ruscus hypoglossum, Tamus communis, but also the other species of mesophilous deciduous forests

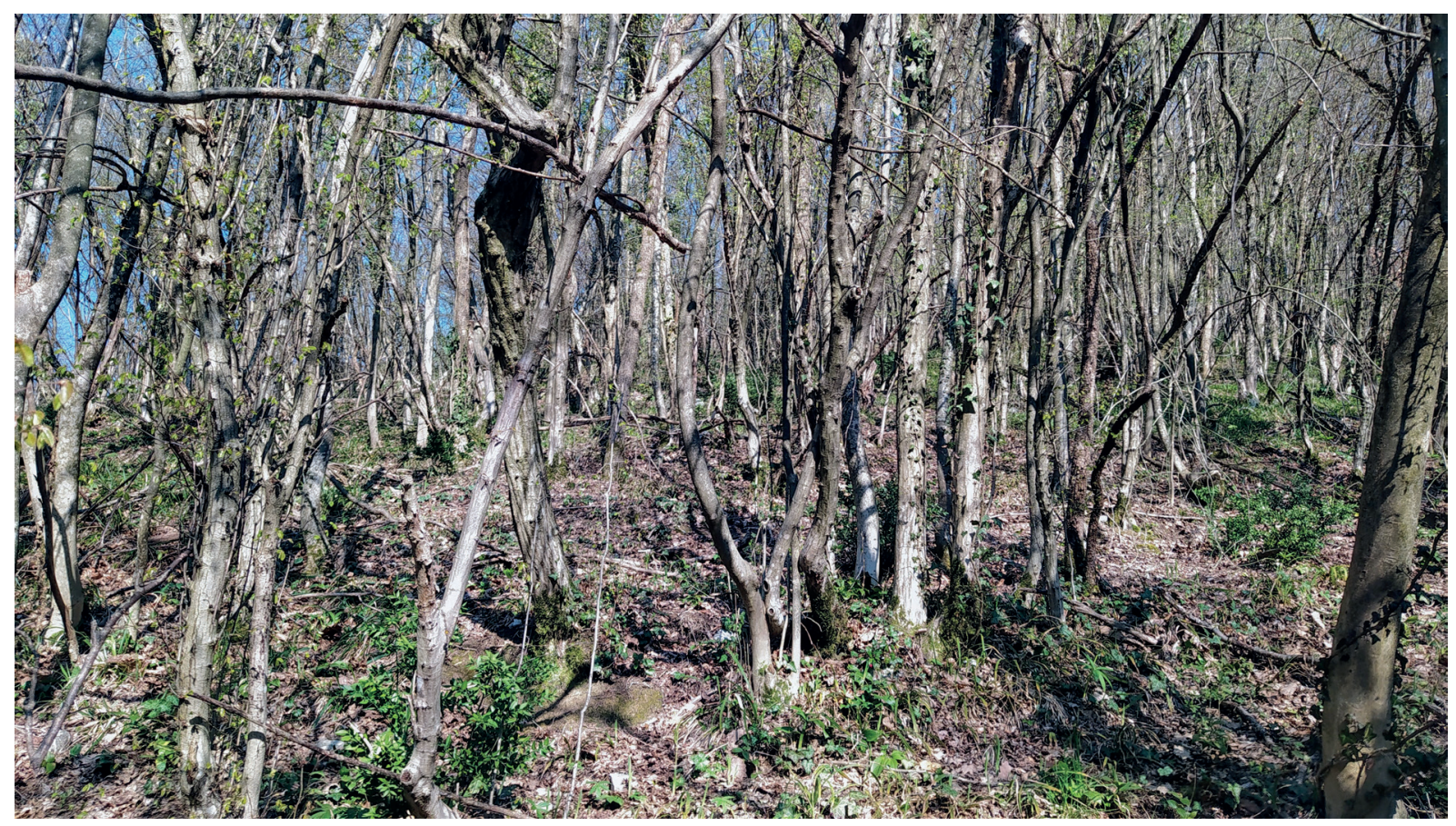

Figure 4: Stand of the association Epimedio alpini-Carpinetum orientalis in Starčevica (Drenovača). Photo: Vladimir Stupar. Slika 4: Sestoj asociacije Epimedio alpini-Carpinetum orientalis pri Starčevici (Drenovača). Foto: Vladimir Stupar. 
(Fagetalia sylvaticae): Ajuga reptans, Aremonia agrimonoides, Asarum europaeum, Brachypodium sylvaticum, Carex pilosa, Cruciata glabra, Drymochloa drymeja, Geum urbanum, Glechoma hirsuta, Hedera helix, Melica uniflora, Polypodium vulgare, Pulmonaria officinalis, Sanicula europaea, Stellaria holostea, Symphytum tuberosum, etc. Fraxinus ornus and Acer obtusatum are usually present in the canopy layer with lower cover values. There are only individual plants of Quercus petraea in the canopy and understory layers, but besides this general lack of $Q$. petraea, the main difference between this association and Aceri obtusati-Quercetum petraeae is lack or low cover and frequency of light-demanding species such as Lathyrus niger, Melittis melissophyllum, Tanacetum corymbosum and Aegonychon purpurocaeruleum in Epimedio-Carpinetum orientalis, all due to light shortage under the closed canopy of $C$. orientalis coppice. Also, the average number of species in Epimedio-Carpinetum orientalis is lower by ten when compared to Aceri obtusati-Quercetum petraeae. The stands of this association were formerly assigned to Cruciato glabrae-Carpinetum orientalis Šugar et Trinajstić ex Stupar et al. 2015 from which they are differentiated by many mesophilous species and lack of the thermophilous Carpinion orientalis species.

\section{Asplenio scolopendrii-Carpinetum orientalis} ass. nova hoc loco (Table 1 column 4)

Typus: Table 3, rel. 6 - holotypus hoc loco

This interesting association is found on "microlocalities" in canyons and gorges of the Vrbas River and its confluences (Figure 1). It is the secondary succession stage of the ravine forests of Ostryo-Tilion. They occupy northern, very steep $\left(35-50^{\circ}\right)$ and stony $(50-80 \%$ of the bare rock) slopes on limestone, and the elevations between 200 and $400 \mathrm{~m}$ a.s.l. These are also coppices with a bushy appearance and height between 7 and 10 m (Figure 5). Although these sites are hardly accessible they are still being regularly coppiced and maintained in a structurally degraded state.

The main species of the canopy layer is Carpinus orientalis, with sometimes admixed tree species of the potential Ostryo-Tilion community: Fraxinus ornus, Ostrya carpinifolia, Tilia tomentosa and Acer monspessulanum. Besides oriental hornbeam, other character species are mesophilous ferns Polystichum setiferum, Asplenium scolopendrium, Asplenium trichomanes, and Polypodium vulgare along with Saxifraga rotundifolia, Veratrum nigrum,

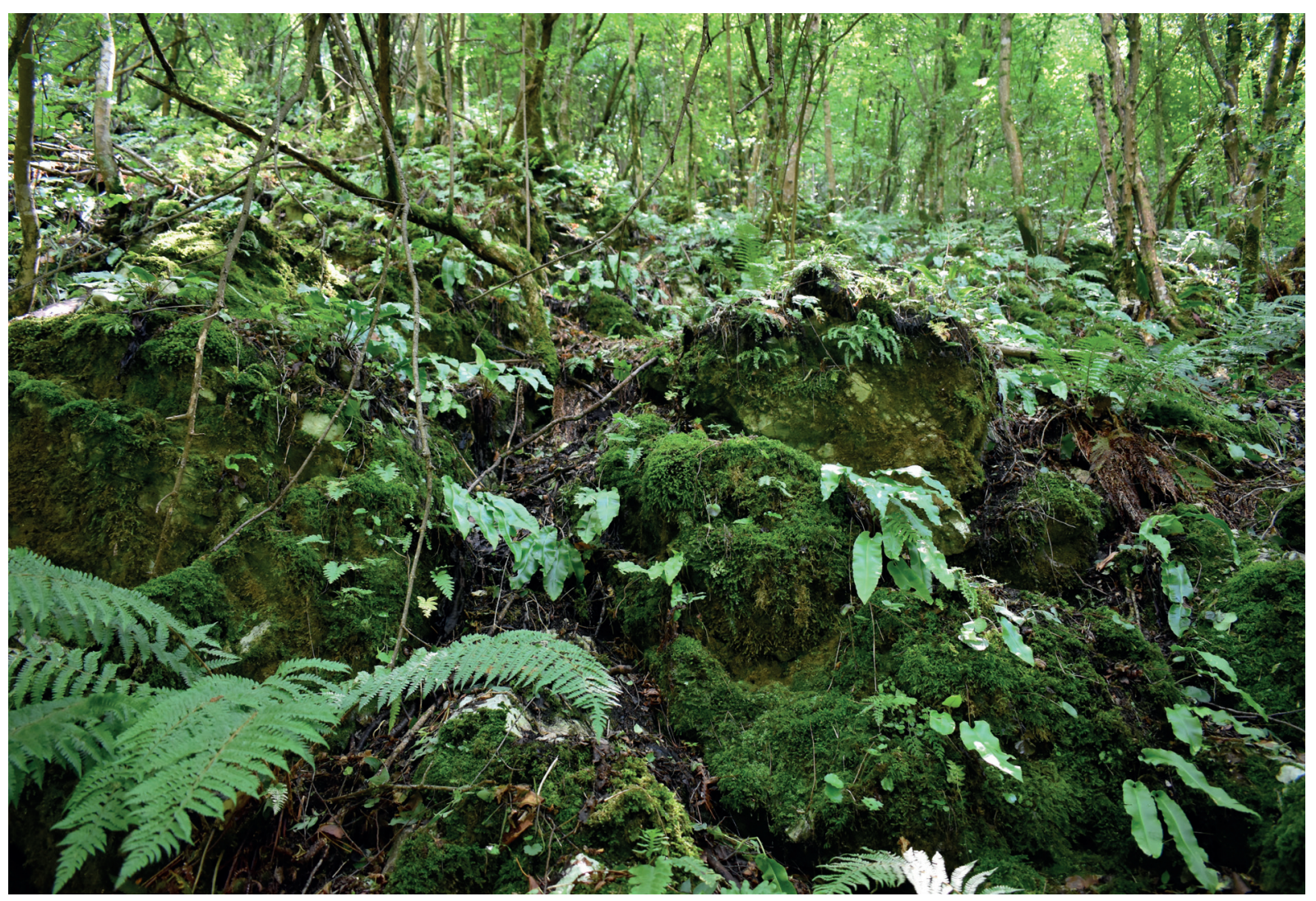

Figure 5: Stand of the association Asplenio scolopendrii-Carpinetum orientalis in Vrbas River canyon. Photo: Ognjen Lukić.

Slika 5: Sestoj asociacije Asplenio scolopendrii-Carpinetum orientalis v kanjonu reke Vrbas. Foto: Ognjen Lukić. 
Geranium robertianum, Carex digitata, and Asplenium ceterach. Among other species characteristic for ravine forests (Ostryo-Tilion) we can find Hedera helix, Helleborus odorus, Hepatica nobilis, Cyclamen purpurascens, etc. Species characteristic for Carpino-Fagetea are also frequent, while of the species characteristic for Quercetea pubescentis there are only Cornus mas and Sesleria autumnalis with higher frequency.

\section{Discussion}

Our results suggest that Epimedio-Carpinetum orientalis is a secondary succession stage of Aceri obtusatiQuercetum petraeae, which is also found over calcareous bedrock in the NW part of B\&H. Although Stupar et al. (2015) treated Aceri obtusati-Quercetum petraeae as a part of thermophilous deciduous forests of Quercetalia pubescentis they did not assign it to any of the alliances in this order, and stated that this association represents the transition from thermophilous forests of Carpinion orientalis towards mesophilous forests of Carpinion betuli (i.e. Erythronio-Carpinion). Although its understory is made of thermophilous species of SE European (Carpinus orientalis, Acer obtusatum, and Fraxinus ornus), and also wider distribution (Cornus mas, Euonymus verrucosus, and Sorbus torminalis), there are also frequent mesophilous elements, such as Carpinus betulus, Acer campestre and Prunus avium. Moreover, the floristic composition of its herb layer is mainly mesophilous, with only several thermophilous species of SE European distribution. All of this is characteristic of Erythronio-Carpinion (Košir et al. 2013, Novák et al. 2020), which is probably where Aceri obtusati-Quercetum petraeae belongs. Although in theory degradation of Aceri obtusati-Quercetum petraeae should be more thermophilous, selective logging of oaks and regular coppicing of the oriental hornbeam resulted in the closed canopy and actually more mesophilous oriental hornbeam coppice of Epimedio-Carpinetum orientalis.

Although we recorded Epimedio-Carpinetum orientalis only in the NW B\&H, there is a mention of oriental hornbeam coppice resulted from the degradation of oak-hornbeam forest (Querco-Carpinetum illyricum typicum) from Lepenica in the central B\&H (Fabijanić et al. 1963). Although there are no relevés for this $C$. orientalis coppice, Querco-Carpinetum illyricum typicum is floristically very similar to Aceri obtusati-Quercetum petraeae (Carpinus betulus together with $C$. orientalis and other thermophilous species in the understory), so it could be expected that the distribution of both, Aceri obtusatiQuercetum petraeae and its degradation stage Epimedio-
Carpinetum orientalis is potentially larger than recorded. It should also be pointed out that Fabijanić et al. (1963) argued that Querco-Carpinetum illyricum typicum is typical oak-hornbeam community (belonging to Carpinion betuli illyrico-podolicum) on calcareous bedrock in B\&H stressing out that it is more thermophilous than originally described climax oak-hornbeam community of continental Croatia Querco-Carpinetum croaticum Horvat 1938 (i.e. Epimedio-Carpinetum betuli).

Although there is an evident floristic similarity between Aceri obtusati-Quercetum petraeae and its secondary successional stage Epimedio-Carpinetum orientalis, there are also clear differences, which reflect in different physiognomy of oriental hornbeam coppice, lack of edifier in the upper layer (Quercus petraea), and the smaller overall number of species per relevé. The latter is due to the closed canopy of oriental hornbeam coppice, which does not allow light to reach the herb layer. Albeit secondary succession stage, light shortage under the closed canopy together with continuous coppicing resulted in the formation of the relatively stable degradation stage which is hard to convert to high forests of Aceri obtusatiQuercetum petraeae. This led us to the conclusion that secondary succession stages of different oak-hornbeam forests, if they are stable, low and dark hornbeam and/ or oriental hornbeam coppices, without upper tree layer, and with the low cover or without oaks, could be treated as separate associations (or at least subassociations) inside the same alliance as their source community. This would also relate better with typologies used in forest management.

However, there is an opinion that some pure oriental hornbeam communities should be classified in its own alliance, as is the case with the Submediterranean thermophilous oriental hornbeam forests of the Central and Southern Balkans of Syringo-Carpinion (Mucina et al. 2016). Their source communities with various oaks are instead being classified into the Amphiadriatic alliance of Carpinion orientalis (Tzonev et al. 2019) although they lack Illyrian species which are replaced with eastern-central Balkan ones. Following this logic, obviously mesophilous Arabido turritae-Carpinetum orientalis Tzonev 2013 (Tzonev 2013) is classified into Syringo-Carpinion orientalis (Tzonev et al. 2009), while floristically it belongs to Erythronio-Carpinion.

Asplenio scolopendrii-Carpinetum orientalis is a member of the Submediterranean ravine forests of Ostryo-Tilion. Although this alliance is very well characterized by its characteristic species combination it was recognized only recently as an independent syntaxon at the level of suballiance (Košir et al. 2008), and then later on raised at the level of alliance (Willner et al. 2016). Stefanović (1979) 
wrote about Aceri-Tilietum mixtum in the canyons of the Dinaric Alps which fits perfectly into the circumscription of the Ostryo-Tilion, although it was not taken into consideration by Košir et al. (2008). Asplenio-Carpinetum is probably the secondary successional stage of this community, occurring on the higher parts of canyon slopes on colder exposures, whereas closer to the river and more humid lower parts are degraded to Ostrya carpinifolia ravine communities.

According to Stefanović (1979), Aceri-Tilietum mixtum with the higher cover of Carpinus orientalis is more common in Neretva and Morača River canyons (Herzegovina and Montenegro) so it can be expected that AsplenioCarpinetum has a larger distribution in the canyons of Dinaric Alps.

Disturbance pattern, along with a high cover of bare rock doesn't allow this community to progress further towards the climax community of Ostryo-Tilion. However, it still has a huge protective role (antierosion) and presents one more authentic forest habitat of $\mathrm{B} \& \mathrm{H}$ canyons.

\section{Acknowledgements}

We would like to thank to two anonymous referees for very valuable comments and suggestions that have significantly improved the first version of the manuscript.

Vladimir Stupar (D), https://orcid.org/0000-0003-0835-2249 Ognjen Lukić (D), https://orcid.org/0000-0003-1279-0647

\section{References}

Anonymous: Meteorological station Banja Luka. Report for the period 1974-2004.

Bergmeier, E. \& Dimopoulos, P. 2008: Identifying plant communities of thermophilous deciduous forest in Greece: Species composition, distribution, ecology and syntaxonomy. Plant Biosystems 142: 228-254.

Blasi, C., Di Pietro, R., Filesi, L. \& Fortini, P. 2001: Syntaxonomy, chorology and dynamics of Carpinus orientalis communities in Central Italy. Phytocoenologia 31: 33-62.

Blečić, V. \& Lakušić, R. 1967: Niederwald und Buschwald der orientalischen Hainbuche in Montenegro. Glasnik Botaničkog zavoda i bašte Univerziteta u Beogradu 2: 83-94.

Braun-Blanquet, J. 1964: Pflanzensoziologie, Grundzüge der Vegetationskunde. 3rd ed. Springer Verlag, Wien, 865 pp.

Bucalo, V. 1999: Šumske fitocenoze planine Jadovnik. Šumarski fakultet Univerziteta u Banjoj Luci, Beograd, RS, 326 pp.

Chytrý, M., Tichý, L., Holt, J. \& Botta-Dukát, Z. 2002: Determination of diagnostic species with statistical fidelity measures. Journal of Vegetation Science 13: 79-90.
Delijanić, I., Radičević, D., Sokolović-Ilić, G., Ivanović, D., Milošević, S. \& Seničar, E. 1964: Klimatska rejonizacija Jugoslavije i tabelarni prikaz temperaturnih i pluviometrijskih karakteristika klimatskih reona Jugoslavije. Jugoslovenski poljoprivredno šumarski centar Beograd: 121-138.

Dengler, J., Jansen, F., Glöckler, F., Peet, R.K., De Cáceres, M., Chytrý, M., Ewald, J., Oldeland, J., Lopez-Gonzalez, G., Finckh, M., Mucina, L., Rodwell, J.S., Schaminée, J.H.J. \& Spencer, N. 2011: The Global Index of Vegetation-Plot Databases (GIVD): a new resource for vegetation science. Journal of Vegetation Science 22: 582-597.

Euro+Med 2006: Euro+Med PlantBase - the information resource for Euro-Mediterranean plant diversity. Available from: http://ww2.bgbm. org/EuroPlusMed/query.asp (October 12, 2015)

Fabijanić, B., Fukarek, P. \& Stefanović, V. 1963: Lepenica: Pregled osnovnih tipova šumske vegetacije. Naučno društvo SR Bosne i Hercegovine, Posebna izdanja 3: 85-129.

Hennekens, S.M. \& Schaminée, J.H.J. 2001: TURBOVEG, a comprehensive data base management system for vegetation data. Journal of Vegetation Science 12: 589-591.

Juvan, N., Košir, P., Marinšek, A., Paušič, A. \& Čarni, A. 2013: Differentiation of the Piceetalia and Athyrio-Piceetalia forests in Slovenia. Tuexenia 33: 25-48.

Kaćanski, D. 1983: Dinamika biocenoza ekosistema rijeke Vrbas (do Jajca). Biološki institut Univerziteta u Sarajevu, Sarajevo, BA,. Elaborat, 66 pp.

Košir, P., Čarni, A. \& Di Pietro, R. 2008: Classification and phytogeographical differentiation of broad-leaved ravine forests in southeastern Europe. Journal of Vegetation Science 19: 331-342.

Košir, P., Casavecchia, S., Čarni, A., Škvorc, Ž., Živković, L. \& Biondi, E. 2013: Ecological and phytogeographical differentiation of oak-hornbeam forests in southeastern Europe. Plant Biosystems 147: 84-98.

Lakušić, R. \& Redžić, S. 1991: Vegetacija refugijalno-reliktnih ekosistema sliva rijeke Une. Bilten Društva ekologa BiH, serija B 6: 25-73.

Marinković, R. \& Ahac, A. 1979: Osnovna geološka karta SFRJ, $1: 100$ 000, list Jajce (sa tumačem). Savezni geološki zavod, Beograd, RS.

McCune, B. \& Mefford, M.J. 1999: PC-ORD. Multivariate Analysis of Ecological Data. Version 5.0. MjM Software, Gleneden Beach, Oregon, US,

Miletić, M., Milanović, Đ., Stupar, V. \& Brujić, J. 2016: Šumska vegetacija Trešnjika kod Banje Luke. Glasnik Šumarskog fakulteta Univerziteta u Banjoj Luci 25: 15-40.

Mojićević, M., Vilovski, S. \& Tomić, B. 1976: Osnovna geološka karta SFRJ, 1:100 000, list Banja Luka (sa tumačem). Savezni geološki zavod, Beograd, RS,

Mucina, L., Bültmann, H., Dierßen, K., Theurillat, J.-P., Raus, T., Čarni, A., Šumberová, K., Willner, W., Dengler, J., García, R.G., Chytrý, M., Hájek, M., Di Pietro, R., Iakushenko, D., Pallas, J., Daniëls, FJ.A., Bergmeier, E., Santos Guerra, A., Ermakov, N., Valachovič, M., Schaminée, J.H.J., Lysenko, T., Didukh, Y.P., Pignatti, S., Rodwell, J.S., Capelo, J., Weber, H.E., Solomeshch, A., Dimopoulos, P., Aguiar, C., Hennekens, S.M. \& Tichý, L. 2016: Vegetation of Europe: hierarchical floristic classification system of vascular plant, bryophyte, lichen, and algal communities. Applied Vegetation Science 19: 3-264. 
Muratspahić, D., Redžić, S. \& Lakušić, R. 1991: Asocijacija RuscoCarpinetum orientalis Bleč. et Lkšić 1966 u dolini rijeke Neretve. Glasnik Republičkog zavoda za zaštitu prirode i Prirodnjačkog muzeja u Podgorici 24: 7-12.

Novák, P., Willner, W., Zukal, D., Kollár, J., Roleček, J., Świerkosz, K., Ewald, J., Wohlgemuth, T., Csiky, J., Onyshchenko, V. \& Chytrý, M. 2020: Oak-hornbeam forests of central Europe: a formalized classification and syntaxonomic revision. Preslia 92: 1-34.

Pignatti, S., Menegoni, P. \& Pietrosanti, S. 2005: Valori di bioindicazione delle piante vascolari della flora d'Italia. BraunBlanquetia 39: 1-97.

Sikkema, R. \& Caudullo, G. 2016: Carpinus orientalis in Europe: distribution, habitat, usage and threats. In: San-Miguel-Ayanz, J., de Rigo, D., Caudullo, G., Houston Durrant, T., \& Mauri, A. (eds.) European Atlas of Forest Tree Species. Publ. Off. EU, Luxembourg, p. e01bf18+.

Stefanović, V. 1979: Fitocenoza javora i lipa (Aceri-Tilietum mixtum, Stef., 1974) u nekim kanjonima Dinarida. Drugi kongres ekologa Jugoslavije. Savez društava ekologa Jugoslavije, Zadar-Plitvice, pp. 1083-1102.

Stefanović, V. 1989: Prilog poznavanju fitogeografskih i fitocenoloških odnosa bjelograbovih šuma izvan klimazonalnog areala u Bosni. Glasnik Zemaljskog muzeja Bosne i Hercegovine, Prirodne nauke, Nova serija 28: 103-119.

Stefanović, V., Beus, V., Burlica, Č., Dizdarević, H. \& Vukorep, I. 1983: Ekološko-vegetacijska rejonizacija Bosne i Hercegovine. Šumarski fakultet u Sarajevu, Posebna izdanja 17: 1-49.

Stefanović, V. \& Manuševa, L. 1971: Šumska vegetacija i zemljišta na andezitu i dacitu istočne Bosne. Radovi Šumarskog fakulteta i Instituta za šumarstvo u Sarajevu 15: 1-83.

Stupar, V., Brujić, J., Škvorc, Ž. \& Čarni, A. 2016: Vegetation types of thermophilous deciduous forests (Quercetea pubescentis) in the Western Balkans. Phytocoenologia 46: 49-68.

Stupar, V., Milanović, Đ., Brujić, J. \& Čarni, A. 2015: Formalized classification and nomenclatural revision of thermophilous deciduous forests (Quercetalia pubescentis) of Bosnia and Herzegovina.

Tuexenia 35: 85-130.
Šugar, I. \& Trinajstić, I. 1988: Prilog poznavanju bjelograbovih šuma u Hrvatskoj. Poljoprivreda i šumarstvo, Titograd 34: 43-51.

Theurillat, J.-P., Willner, W., Fernández-González, F., Bültmann, H., Čarni, A., Gigante, D., Mucina, L. \& Weber, H. 2020: International Code of Phytosociological Nomenclature. 4th edition. Applied Vegetation Science. https://doi.org/10.1111/avsc.12491

Tichý, L. 2002: JUICE, software for vegetation classification. Journal of Vegetation Science 13: 451-453.

Tomić, Z. \& Rakonjac, L. 2013: Šumske fitocenoze Srbije: Priručnik za šumare, ekologe i biologe. Univerzitet Singidunum, Fakultet za primenjenu ekologiju Futura i Institut za šumarstvo, Beograd, 177 pp.

Tzonev, R. 2013: New plant associations from Danubian Plain, Bulgaria. Phytologia Balcanica 19: 243-266.

Tzonev, R., Dimitrov, M., Gussev, C., Pachedjieva, K., Gogushev, G., Apostolova-Stoyanova, N., Nikolov, I., Alexandrova, A. \& Glogov, P. 2019: Phytosociological classification of the thermophilous oak forests in Bulgaria: new interpretations and gaps in knowledge. Phytocoenologia 49: 369-391.

Tzonev, R., Dimitrov, M. \& Roussakova, V. 2009: Syntaxa according to the Braun-Blanquet approach in Bulgaria. Phytologia Balcanica 15: 209-233.

Vukelić, J. 2012: Šumska vegetacija Hrvatske. Šumarski fakultet, Sveučilište u Zagrebu, DZZP, Zagreb, 403 pp.

Willner, W., Solomeshch, A., Čarni, A., Bergmeier, E., Ermakov, N. \& Mucina, L. 2016: Description and validation of some European forest syntaxa - a supplement to the EuroVegChecklist. Hacquetia 15: $15-25$.

Zelený, D. \& Schaffers, A.P. 2012: Too good to be true: pitfalls of using mean Ellenberg indicator values in vegetation analyses. Journal of Vegetation Science 23: 419-431. 
Table 1: Frequency-fidelity table of Carpinus orientalis coppice communities in B\&H (fidelity value in superscript multiplied by 100). Diagnostic species (phi values higher than 0.25 ) for each community are shaded (only species with the phi value higher than 0.4 are presented). Cluster numbers correspond to those used throughout the text.

Tabela 1: Tabela frekvenc in navezanosti panjevski združb vrste Carpinus orientalis v B\&H (nadpisane vrednosti navezanosti vrst so pomnožene s 100). Diagnostične vrste (fi vrednosti večje od) vsake združbe so zasenčene (prikazane so samo vrste s fi vrednostjo, večjo od 0,4 ). Številke klastrov so enake kot v besedilu.

\begin{tabular}{|c|c|c|c|c|c|c|c|c|c|}
\hline Group number & 1 & 2 & 3 & 4 & Group number & 1 & 2 & 3 & 4 \\
\hline No. of relevés & 12 & 50 & 33 & 8 & No. of relevés & 12 & 50 & 33 & 8 \\
\hline \multicolumn{5}{|c|}{ Rusco aculeati-Carpinetum orientalis } & Luzula forsteri & . & . & $30^{49,6}$ & . \\
\hline Paliurus spina-christi & 8387,4 & 2 & . & . & Sorbus torminalis & 8 & 20 & $55^{48,2}$ & . \\
\hline Asparagus acutifolius & $58^{69,8}$ & 2 & . & . & Glechoma hirsuta & 8 & 32 & $79^{46,9}$ & 38 \\
\hline Rubus ulmifolius & $58^{68,1}$ & 4 & . & . & Drymochloa drymeja & . & . & 2746,9 & . \\
\hline Petteria ramentacea & $50^{63,5}$ & 2 & . & . & Sanicula europaea & . & 2 & $27^{44,2}$ & . \\
\hline Brachypodium pinnatum & 5863,3 & 10 & . & . & Stellaria holostea & . & 6 & 4243,7 & 12 \\
\hline Acer monspessulanum & $100^{63}$ & 14 & 6 & 62 & Aremonia agrimonoides & . & 12 & $55^{43,5}$ & 25 \\
\hline Viola alba & 6761,8 & 10 & 12 & . & Hedera helix & 50 & 24 & 9442,4 & 62 \\
\hline Pistacia terebinthus & 4259,1 & . & . & . & Brachypodium sylvaticum & 25 & 14 & $73^{42,3}$ & 38 \\
\hline Clematis flammula & $42^{59,1}$ & . & . & . & Epimedium alpinum & . & 2 & 3641 & 12 \\
\hline Satureja montana & $33^{49,8}$ & 2 & . & . & \multicolumn{5}{|c|}{ Asplenio scolopendrium-Carpinetum orientalis } \\
\hline \multicolumn{5}{|c|}{ Cruciato glabrae-Carpinetum orientalis } & Saxifraga rotundifolia & . & . & 6 & $100^{96,1}$ \\
\hline Thymus pulegioides ssp. montanus & 8 & 7671,8 & 9 & . & Veratrum nigrum & . & 10 & . & 10093,7 \\
\hline Euphorbia cyparissias & . & $62^{69,1}$ & 6 & . & Polystichum setiferum & . & 2 & 27 & $100^{83,6}$ \\
\hline Origanum vulgare & . & 3654,5 & . & . & Asplenium scolopendrium & . & 2 & 15 & $88^{80,6}$ \\
\hline Galium lucidum & 8 & 5252,8 & 9 & . & Carex digitata & . & 10 & 36 & $100^{76}$ \\
\hline Teucrium chamaedrys & 75 & $88^{52,4}$ & 9 & . & Hepatica nobilis & . & 8 & 33 & $88^{68,3}$ \\
\hline Bromus erectus agg. & 8 & $48^{51,6}$ & 6 & . & Geranium robertianum & 17 & 4 & 24 & 8866,7 \\
\hline \multirow{2}{*}{$\begin{array}{l}\text { Dorycnium pentaphyllum ssp. } \\
\text { germanicum }\end{array}$} & \multirow[t]{2}{*}{. } & \multirow[t]{2}{*}{$30^{49,3}$} & \multirow[t]{2}{*}{. } & \multirow[t]{2}{*}{. } & Valeriana officinalis & . & 2 & . & 5063,5 \\
\hline & & & & & Asplenium trichomanes & 25 & 22 & 39 & $100^{61,8}$ \\
\hline Stachys recta & . & 2847,5 & . & $\cdot$ & Peltaria alliacea & . & 4 & 15 & $62^{60,3}$ \\
\hline Lotus corniculatus & 8 & 3645,8 & . & . & Lamium galeobdolon & . & 8 & 12 & 6259,7 \\
\hline Filipendula vulgaris & . & $30^{45,6}$ & 3 & $\cdot$ & Mercurialis perennis & . & 2 & 18 & 6259,6 \\
\hline Sedum acre & . & $30^{45,6}$ & 3 & . & Sambucus nigra & . & . & . & 3855,7 \\
\hline Cytisus hirsutus & . & 3844,4 & 12 & . & Galium schultesii & . & . & 12 & 5054,9 \\
\hline Pilosella officinarum & 8 & 3443,9 & . & . & Galium sylvaticum & . & . & 12 & 5054,9 \\
\hline Juniperus communis & . & $48^{43,1}$ & 27 & . & Polypodium vulgare & . & 2 & 6127,5 & $88^{59,6}$ \\
\hline Scabiosa cinerea ssp. cinerea & $\cdot$ & $22^{41,8}$ & . & . & \multicolumn{5}{|c|}{ Other species with high frequency } \\
\hline \multicolumn{4}{|c|}{ Epimedio alpinum-Carpinetum orientalis } & & Carpinus orientalis & 100 & 100 & 100 & 100 \\
\hline Cruciata glabra & 8 & 24 & $85^{64,7}$ & 12 & Sesleria autumnalis & 100 & 76 & 24 & 75 \\
\hline Quercus petraea & . & 26 & 6759,5 & $\cdot$ & Crataegus monogyna & 58 & 54 & 76 & 38 \\
\hline Rosa arvensis & . & 34 & 7959,1 & 12 & Fraxinus ornus & 75 & 94 & 91 & 88 \\
\hline Festuca heterophylla & 17 & 8 & 6457,9 & . & Cornus mas & 25 & 60 & 79 & 100 \\
\hline Ajuga reptans & 8 & 6 & $55^{57,1}$ & . & Asplenium ceterach & 50 & 30 & 30 & 88 \\
\hline Cyclamen purpurascens & . & 20 & 8554,7 & 50 & Ruscus aculeatus & 75 & 16 & 48 & 25 \\
\hline Acer obtusatum & 8 & 44 & 7654,1 & . & & & & & \\
\hline Helleborus odorus & . & 42 & 10053 & 75 & & & & & \\
\hline Carpinus betulus & . & 12 & 4551,2 & . & & & & & \\
\hline Acer tataricum & . & 6 & 3951 & . & & & & & \\
\hline Lathyrus vernus & . & 4 & $36^{50,4}$ & . & & & & & \\
\hline
\end{tabular}


Table 2: Epimedio alpini-Carpinetum orientalis ass. nov. hoc loco, holotypus: relevé 11 (A - canopy layer (>5 m), $\mathrm{B}$ - understory layer $(<5 \mathrm{~m}), \mathrm{C}$ - herb layer).

Tabela 2: Epimedio alpini-Carpinetum orientalis ass. nov. hoc loco, holotip: popis 11 (A - drevesna plast $(>5 \mathrm{~m})$, $\mathrm{B}$ - grmovna plast $(<5 \mathrm{~m}), \mathrm{C}$ - zeliščna plast).

\begin{tabular}{lcccccccccccccccc}
\hline Relevé number & 1 & 2 & 3 & 4 & 5 & 6 & 7 & 8 & 9 & 10 & 11 & 12 & 13 & 14 & 15 \\
Relevé area (m2) & 100 & 100 & 100 & 225 & 400 & 400 & 400 & 400 & 400 & 400 & 400 & 400 & 400 & 400 & 225 \\
Altitude (m) & 340 & 390 & 477 & 310 & 370 & 340 & 308 & 543 & 552 & 523 & 230 & 323 & 258 & 270 & 280 \\
Aspect & SE & SE & S & W & E & W & SW & SE & E & S & E & SE & SE & SE & W \\
Slope (degrees) & 5 & 25 & 15 & 35 & 25 & 25 & 15 & 5 & 5 & 3 & 15 & 3 & 7 & 10 & 35 \\
Hight of the canopy layer (m) & 6 & 9 & 8 & 8 & 10 & 9 & 4 & 6 & 6 & 6 & 7 & 8 & 9 & 8 & 13 \\
Cover total (\%) & 100 & 90 & 100 & 80 & 70 & 95 & 95 & 80 & 90 & 80 & 90 & 90 & 70 & 80 & 100 \\
Cover A (\%) & 100 & 90 & 100 & 80 & 100 & 90 & 0 & 80 & 90 & 80 & 90 & 90 & 70 & 80 & 60 \\
Cover B (\%) & 20 & 50 & 50 & 25 & 25 & 20 & 90 & 20 & 10 & 10 & 20 & 20 & 50 & 40 & 15 \\
Cover C (\%) & 5 & 60 & 20 & 50 & 90 & 60 & 20 & 30 & 20 & 40 & 30 & 20 & 90 & 90 & 70 \\
Cover bare rock (\%) & 50 & 0 & 10 & 0 & 0 & 20 & 0 & 10 & 10 & 40 & 5 & 0 & 20 & 20 & 0 \\
\hline
\end{tabular}

\section{Characteristic species of the association}

Carpinus orientalis

Carpinus orientalis

Acer obtusatum

Acer obtusatum

Potentilla micrantha

Brachypodium sylvaticum

Lathyrus vernus+venetus

Glechoma hirsuta

Pulmonaria officinalis

Festuca heterophylla

Asarum europaeum

Polypodium vulgare

\section{Erythronio-Carpinion}

Carpinus betulus

Carpinus betulus

Ruscus aculeatus

Ruscus hypoglossum

Helleborus odorus

Cyclamen purpurascens

Primula acaulis

Epimedium alpinum

Tamus communis

\section{Carpino-Fagetea}

Crataegus monogyna

Crataegus monogyna

Quercus petraea

Quercus petraea

Acer campestre

\begin{tabular}{|c|c|c|c|c|c|c|c|c|c|c|c|c|c|c|}
\hline A & 5 & 4 & 5 & 4 & 4 & 4 & . & 4 & 4 & 4 & 5 & 5 & 4 & 4 \\
\hline B & 1 & . & . & 1 & 1 & 1 & 4 & 2 & 2 & ? & 1 & 2 & 1 & 1 \\
\hline A & . & 1 & 1 & . & 1 & 2 & . & + & . & & & . & & . \\
\hline B & + & . & + & + & 2 & + & . & + & . & 2 & 2 & + & + & + \\
\hline C & + & . & + & + & + & . & + & 1 & + & 1 & $t$ & 1 & + & + \\
\hline $\mathrm{C}$ & 1 & 3 & + & 1 & . & . & 1 & 1 & 1 & 1 & + & 1 & 2 & 1 \\
\hline $\mathrm{C}$ & . & 1 & + & . & + & + & . & + & + & & $\mathrm{r}$ & + & 1 & + \\
\hline $\mathrm{C}$ & + & . & . & + & . & . & 1 & 1 & 1 & & 1 & + & 1 & 1 \\
\hline $\mathrm{C}$ & $\mathrm{r}$ & . & . & + & . & . & + & + & 1 & & + & $\mathrm{r}$ & + & + \\
\hline $\mathrm{C}$ & . & + & 2 & . & . & . & 1 & 1 & $\mathrm{r}$ & & + & 1 & 1 & 1 \\
\hline $\mathrm{C}$ & . & + & . & . & + & . & + & 1 & $\mathrm{r}$ & & + & + & 1 & 1 \\
\hline $\mathrm{C}$ & . & + & . & + & + & . & + & $\mathrm{r}$ & $\mathrm{r}$ & + & . & . & + & . \\
\hline
\end{tabular}




\begin{tabular}{|c|c|c|c|c|c|c|c|c|c|c|c|c|c|c|c|c|}
\hline Relevé number & & 1 & 2 & 3 & 4 & 5 & 6 & 7 & 8 & 9 & 10 & 11 & 12 & 13 & 14 & 15 \\
\hline Acer campestre & $\mathrm{B}$ & 1 & . & + & + & + & 2 & 2 & . & . & . & 2 & + & + & . & 1 \\
\hline Rosa arvensis & $\mathrm{B}$ & 1 & + & + & + & + & . & . & + & + & + & + & + & + & + & + \\
\hline Hedera helix & $\mathrm{B}$ & 1 & 2 & 1 & 3 & 1 & 1 & . & 1 & 1 & 2 & + & . & 1 & 2 & 3 \\
\hline Ligustrum vulgare & $\mathrm{B}$ & . & 1 & . & + & . & 1 & 1 & + & + & 1 & 1 & + & + & + & . \\
\hline Clematis vitalba & $\mathrm{B}$ & $\mathrm{r}$ & + & . & . & + & . & + & r & 1 & . & . & + & $\mathrm{r}$ & . & . \\
\hline Rubus hirtus & $\mathrm{B}$ & . & . & . & . & . & + & + & + & + & . & + & . & . & . & . \\
\hline Corylus avellana & B & . & . & . & . & . & + & 1 & . & . & . & $\mathrm{r}$ & . & . & . & . \\
\hline Cruciata glabra & $\mathrm{C}$ & . & 3 & + & + & + & . & + & + & + & + & 1 & 1 & + & + & + \\
\hline Aremonia agrimonoides & $\mathrm{C}$ & + & . & . & . & . & . & 1 & 1 & 1 & + & . & + & + & + & . \\
\hline Symphytum tuberosum & $\mathrm{C}$ & . & + & + & . & + & + & . & r & . & . & + & + & + & $\mathrm{r}$ & . \\
\hline Ajuga reptans & $\mathrm{C}$ & + & 1 & . & + & . & . & 1 & . & . & . & $\mathrm{r}$ & . & + & + & $\mathrm{r}$ \\
\hline Dactylis glomerata & C & + & . & + & + & . & + & . & + & . & + & . & . & . & . & + \\
\hline Carex sylvatica & $\mathrm{C}$ & + & . & . & . & . & . & + & + & + & . & . & + & 2 & 1 & . \\
\hline Luzula forsteri & C & . & . & + & . & . & . & . & $\mathrm{r}$ & + & + & . & + & + & 1 & . \\
\hline Carex digitata & $\mathrm{C}$ & . & . & . & + & + & 1 & . & . & . & . & + & . & 1 & 2 & $\mathrm{r}$ \\
\hline Sanicula europaea & $\mathrm{C}$ & . & + & . & . & . & . & . & + & . & . & + & + & . & + & . \\
\hline Drymochloa drymeia & C & . & . & . & + & 5 & 1 & . & + & . & + & . & . & . & . & . \\
\hline Hepatica nobilis & $\mathrm{C}$ & . & . & . & + & . & + & . & . & . & . & + & . & + & 1 & . \\
\hline Euphorbia amygdaloides & $\mathrm{C}$ & . & . & . & $\mathrm{r}$ & . & . & . & . & . & . & + & . & + & + & + \\
\hline Stellaria holostea & $\mathrm{C}$ & . & + & . & . & . & . & . & . & + & 1 & . & . & 1 & . & . \\
\hline Bromus benekenii & $\mathrm{C}$ & . & . & $\mathrm{r}$ & . & . & . & . & . & . & $\mathrm{r}$ & + & . & . & . & 2 \\
\hline Daphne laureola & $\mathrm{B}$ & . & . & . & + & . & . & . & + & + & . & . & . & . & . & + \\
\hline Polystichum setiferum & $\mathrm{C}$ & . & . & . & + & . & . & . & r & + & . & . & . & . & . & + \\
\hline Geum urbanum & $\mathrm{C}$ & . & . & . & + & . & . & . & . & $\mathrm{r}$ & + & . & . & + & . & . \\
\hline Viola reichenbachiana & C & . & . & . & . & . & . & + & . & + & . & + & + & . & . & . \\
\hline Melica uniflora & C & . & + & + & . & . & . & . & . & $\mathrm{r}$ & . & . & . & . & . & . \\
\hline Veronica chamaedrys & $\mathrm{C}$ & . & . & + & + & . & $\mathrm{r}$ & . & . & . & . & . & . & . & $\cdot$ & . \\
\hline Galium schultesii & C & . & . & r & $\mathrm{r}$ & . & . & . & . & . & . & . & . & . & + & . \\
\hline Carex pilosa & C & . & . & . & . & . & 3 & . & . & . & . & . & . & + & 3 & . \\
\hline \multicolumn{17}{|l|}{ Quercetea pubescentis } \\
\hline Fraxinus ornus & A & 2 & 2 & 1 & 2 & 3 & 2 & . & . & + & 1 & + & + & 1 & 1 & . \\
\hline Fraxinus ornus & $\mathrm{B}$ & 2 & . & 1 & + & + & 2 & . & . & 2 & 2 & 2 & 2 & 1 & 1 & . \\
\hline Euonymus verrucosus & $\mathrm{B}$ & . & 2 & . & + & 1 & $\mathrm{r}$ & . & . & . & + & + & . & + & 1 & . \\
\hline Cornus mas & A & 1 & . & . & . & 1 & 1 & . & . & . & . & . & . & . & 1 & . \\
\hline Cornus mas & $\mathrm{B}$ & + & . & . & 2 & . & 1 & 2 & . & 2 & . & 1 & . & 1 & 2 & 2 \\
\hline Sorbus torminalis & A & 1 & . & 2 & . & . & . & . & . & . & . & . & . & . & . & . \\
\hline Sorbus torminalis & $\mathrm{B}$ & 1 & . & + & + & . & . & . & . & . & . & 2 & 1 & 1 & . & 1 \\
\hline Cotinus coggygria & A & 1 & . & . & . & . & . & . & . & . & . & . & . & $\cdot$ & . & . \\
\hline Cotinus coggygria & $\mathrm{B}$ & 1 & . & . & . & + & . & . & . & . & . & . & . & + & . & + \\
\hline Viburnum lantana & $\mathrm{B}$ & + & 1 & . & . & 2 & . & + & . & . & . & + & . & 1 & . & + \\
\hline Tilia tomentosa & $\mathrm{B}$ & . & . & . & . & + & 2 & . & . & . & . & . & . & 1 & . & . \\
\hline Carex flacca & $\mathrm{C}$ & . & . & . & + & . & . & 1 & . & . & . & 2 & 1 & . & $\mathrm{r}$ & . \\
\hline Viola hirta & C & + & . & + & + & + & . & . & . & . & . & . & + & . & . & . \\
\hline Campanula persicifolia & $\mathrm{C}$ & . & . & + & + & + & + & . & + & . & . & . & . & . & . & . \\
\hline
\end{tabular}




\begin{tabular}{|c|c|c|c|c|c|c|c|c|c|c|c|c|c|c|c|c|}
\hline Relevé number & & 1 & 2 & 3 & 4 & 5 & 6 & 7 & 8 & 9 & 10 & 11 & 12 & 13 & 14 & 15 \\
\hline Lathyrus niger & $\mathrm{C}$ & r & . & + & . & + & . & . & . & . & . & . & . & + & . & . \\
\hline Melittis melissophyllum & $\mathrm{C}$ & . & + & . & . & + & . & . & . & . & . & $\cdot$ & - & . & $\cdot$ & + \\
\hline Aegonychon purpurocaeruleum & $\mathrm{C}$ & 1 & . & + & + & . & . & . & . & . & . & . & . & . & . & . \\
\hline Asplenium adiantum-nigrum & $\mathrm{C}$ & . & $\cdot$ & $\cdot$ & + & . & + & $\cdot$ & $\cdot$ & . & . & . & . & . & . & + \\
\hline Asplenium ceterach & $\mathrm{C}$ & . & . & . & + & . & . & . & . & $\mathrm{r}$ & + & . & . & . & . & . \\
\hline Allium carinatum & C & . & $\cdot$ & $\cdot$ & . & . & $\cdot$ & . & $\mathrm{r}$ & + & r & . & . & . & . & $\cdot$ \\
\hline Silene nutans & $\mathrm{C}$ & . & . & $\cdot$ & . & . & . & . & $\cdot$ & . & 1 & . & . & + & + & . \\
\hline \multicolumn{17}{|l|}{ Companions } \\
\hline Acer tataricum & B & r & $\cdot$ & $\mathrm{r}$ & + & + & . & . & . & . & . & + & . & 1 & 1 & . \\
\hline Juniperus communis & $\mathrm{B}$ & + & + & . & . & . & . & + & $\mathrm{r}$ & . & . & . & + & + & . & . \\
\hline Asplenium trichomanes & $\mathrm{C}$ & . & . & . & + & . & . & . & . & $\mathrm{r}$ & . & . & . & . & . & + \\
\hline
\end{tabular}

In one or two relevés:

A: Sorbus torminalis 1: 1, 3: 2; Cotinus coggygria 1: 1; Quercus cerris 2: +; Tilia tomentosa 5: 1, 6: 1; Ostrya carpinifolia 9: +, 10: +; Quercus pubescens 1: 1; Prunus avium 9: +; Fagus sylvatica 12: +; Fraxinus excelsior 15: 1;

B: Cornus sanguinea 2: +; Quercus cerris 7: 2; Pyrus communis ssp. pyraster 1:+, 12: +; Fagus sylvatica 3: +, 7: 2; Staphylea pinnata 4: +, 5: 2; Euonymus latifolius 4: +, 5: +; Euonymus europaeus 7: +, 11:+; Ostrya carpinifolia 9: 2, 10: 2; Prunus avium 9: 2, 11:2; Quercus pubescens 1: 1; Prunus spinosa 1: r; Rhamnus cathartica 2: 1; Cytisus hirsutus 2: 1; Ulmus minor 8: +; Tilia platyphyllos 8: r; Quercus robur 13: 2; Tilia cordata 15: +; Fraxinus excelsior 15: +;

C: Sesleria autumnalis 8: +, 14: +; Cephalanthera longifolia 2: +, 7: r; Mercurialis perennis 4: +, 15: +; Iris graminea 4: 1; Lilium martagon 5: +; Pteridium aquilinum 7: +; Vincetoxicum hirundinaria 1: r, 4: +; Melica nutans 2: 1, 4: +; Melampyrum pratense 2: +, 4: +; Aristolochia lutea 2: +, 7: 1; Galium sylvaticum 2: +, 11:+; Fragaria vesca 2: +, 15: +; Campanula trachelium 3: +, 4: +; Polygonatum multiflorum 3:+, 9:+; Hylotelephium maximum 3: +, 11: r; Pseudoturritis turrita 4: +, 9: +; Asplenium scolopendrium 4: +, 15: +; Cardamine bulbifera 6: +, 9: +; Galanthus nivalis 6: r, 9: +; Taraxacum officinale 8: r, 9: r; Peltaria alliacea 9: +, 10: +; Arum maculatum 9: +, 11: +; Geranium robertianum 9: r, 10: +; Aposeris foetida 11: 1, 12: 1; Melampyrum nemorosum 11: +, 14: +; Galium verum 2: 2; Thymus pulegioides 2: +; Poa angustifolia 2: +; Luzula campestris 2: +; Asplenium ruta-muraria 2: +; Chaerophyllum hirsutum 3: r; Platanthera bifolia 3: r; Holcus lanatus 3: r; Lamium galeobdolon 4: +; Peucedanum austriacum 4: +; Piptatherum virescens 4: +; Silene viridiflora 4: +; Polygonatum odoratum 4: r; Anemone ranunculoides 6: +; Erythronium dens-canis 6: +; Orchis pallens 6: r; Orchis simia 7: +; Campanula bononiensis 7: r; Filipendula vulgaris 7: r; Corydalis cava 9: +; Neottia nidus-avis 9: +; Crocus vernus 9: +; Scilla bifolia 9: r; Galium mollugo 10: +; Orchis purpurea 11: 1; Anemone nemorosa 11: +; Smyrnium perfoliatum 13: +; Ornithogalum pyrenaicum 13: +; Peucedanum carvifolia 13: r; Pastinaca sativa 14: r.

Details of relevés (indicated in the following order: relevé number, GIVD EU-BA-001 relevé number, date (year/month/day), description of locality, longitude, latitude, bedrock): 1) 309, 2014/06/24, Ćićina kosa, Gradina (Bočac), 17.147586, 44.545781, limestone; 2) 1073, 1998/04/28, Cer (Starčevica), 17.212744, 44.7504, dolomite; 3) 3026, 2017/05/02, Jagare (Starčevica), 17.207547, 44.712043, limestone; 4) 3579, 2014/08/19, Magareći potok (Starčevica), 17.184836, 44.745235, dolomite; 5) 3580, 2014/07/31, Trešnjik (Starčevica), 17.17307 , 44.73713, dolomite; 6) 3632, 2020/04/03, Drenovača (Ponir), 17.221471, 44.747957, limestone; 7) 3636, 2020/04/05, Donja Kola (Manjača), 17.090543, 44.749972, dolomite; 8) 3638, 2020/04/09, above Vrbas canyon (Ljubačevo), 17.18372, 44.683289, limestone; 9) 3639, 2020/04/09, above Vrbas canyon (Ljubačevo), 17.184923, 44.682865, limestone; 10) 3640, 2020/04/09, Grabež Mala (Ljubačevo), 17.187266, 44.680652, limestone; 11) 3642, 2020/04/09, Savići (Rekavice), 17.13603, 44.674709, limestone; 12) 3643, 2020/04/09, Rekavice, 17.131842, 44.679936, marl limestone; 13) 3644, 2020/04/10, Krupa na Vrbasu, 17.135722, 44.617552, limestone; 14) 3645, 2020/04/10, Krupa na Vrbasu, 17.137349, 44.618658, limestone; 15) 3578, 2014/07/30, Banj brdo (Starčevica), 17.174481, 44.746997, dolomite. 
Table 3: Asplenio scolopendrii-Carpinetum orientalis ass. nov. hoc loco, holotypus: relevé 6 (A - canopy layer (> $5 \mathrm{~m})$, $\mathrm{B}$ - understory layer ( $<5 \mathrm{~m}), \mathrm{C}$ - herb layer).

Tabela 3: Asplenio scolopendrii-Carpinetum orientalis ass. nov. hoc loco, holotip: popis 6 (A - drevesna plast (> $5 \mathrm{~m})$, $\mathrm{B}$ - grmovna plast $(<5 \mathrm{~m}), \mathrm{C}-$ zeliščna plast).

\begin{tabular}{lcccccccc}
\hline Relevé number & 1 & 2 & 3 & 4 & 5 & 6 & 7 & 8 \\
Relevé area (m2) & 400 & 100 & 400 & 100 & 400 & 400 & 225 & 225 \\
Altitude (m) & 313 & 330 & 350 & 215 & 317 & 406 & 220 & 230 \\
Aspect & $\mathrm{NE}$ & $\mathrm{NE}$ & $\mathrm{N}$ & $\mathrm{NW}$ & $\mathrm{E}$ & $\mathrm{N}$ & $\mathrm{NW}$ & $\mathrm{NE}$ \\
Slope (degrees) & 45 & 45 & 50 & 45 & 35 & 40 & 35 & 50 \\
Hight of the canopy layer (m) & 8 & 8 & 7 & 10 & 10 & 8 & 8 & 10 \\
Cover total (\%) & 100 & 100 & 100 & 100 & 80 & 100 & 100 & 85 \\
Cover A (\%) & 100 & 100 & 100 & 90 & 80 & 100 & 45 & 80 \\
Cover B (\%) & 20 & 10 & 0 & 30 & 50 & 30 & 80 & 25 \\
Cover C (\%) & 60 & 50 & 50 & 50 & 50 & 80 & 40 & 50 \\
Cover bare rock (\%) & 80 & 50 & 70 & 90 & 75 & 60 & 50 & 80 \\
\hline
\end{tabular}

\begin{tabular}{|c|c|c|c|c|c|c|c|c|c|}
\hline \multicolumn{10}{|c|}{ Characteristic species of the association } \\
\hline Carpinus orientalis & A & 5 & 3 & 4 & 5 & 4 & 5 & 1 & 5 \\
\hline Carpinus orientalis & $\mathrm{B}$ & 2 & + & 2 & 2 & 2 & 2 & 3 & . \\
\hline Polystichum setiferum & $\mathrm{C}$ & 4 & + & 3 & 2 & 1 & 1 & 2 & 3 \\
\hline Asplenium scolopendrium & $\mathrm{C}$ & 3 & 2 & 2 & 2 & 2 & 1 & 2 & 2 \\
\hline Asplenium trichomanes & $\mathrm{C}$ & 1 & 1 & + & + & 1 & + & 1 & 1 \\
\hline Asplenium ceterach & $\mathrm{C}$ & + & + & . & + & 1 & + & + & + \\
\hline Polypodium vulgare & $\mathrm{C}$ & 1 & . & 2 & 1 & 3 & 2 & 1 & 1 \\
\hline Saxifraga rotundifolia & $\mathrm{C}$ & + & + & 1 & + & + & 1 & + & + \\
\hline Veratrum nigrum & $\mathrm{C}$ & 2 & 1 & 2 & + & . & + & $\mathrm{r}$ & + \\
\hline Geranium robertianum & $\mathrm{C}$ & 1 & + & + & + & 1 & . & + & + \\
\hline Carex digitata & $\mathrm{C}$ & + & + & + & + & . & + & + & + \\
\hline \multicolumn{10}{|l|}{ Ostryo-Tilion } \\
\hline Fraxinus ornus & A & 1 & 2 & 3 & . & 2 & 1 & 1 & 1 \\
\hline Fraxinus ornus & $\mathrm{B}$ & 2 & 1 & 2 & . & 2 & 2 & 2 & + \\
\hline Ostrya carpinifolia & A & . & 2 & . & 1 & 1 & . & 2 & 1 \\
\hline Ostrya carpinifolia & $\mathrm{B}$ & . & . & . & . & . & + & 2 & . \\
\hline Tilia tomentosa & A & 1 & . & 1 & . & . & . & . & . \\
\hline Tilia tomentosa & $\mathrm{B}$ & 1 & . & + & . & . & 1 & . & . \\
\hline Acer monspessulanum & A & + & 1 & 1 & 1 & . & . & . & . \\
\hline Hedera helix & $\mathrm{B}$ & + & . & + & + & 2 & . & + & + \\
\hline Euonymus verrucosus & $\mathrm{B}$ & . & + & + & + & . & . & + & 1 \\
\hline Staphylea pinnata & A & + & 2 & . & . & . & . & . & . \\
\hline Staphylea pinnata & $\mathrm{B}$ & + & 1 & . & . & . & . & 2 & . \\
\hline Sambucus nigra & $\mathrm{B}$ & . & . & . & + & . & . & 2 & + \\
\hline Tilia platyphyllos & $\mathrm{B}$ & . & . & . & + & . & . & + & + \\
\hline Helleborus odorus & $\mathrm{C}$ & 1 & . & + & + & + & 1 & + & + \\
\hline Hepatica nobilis & $\mathrm{C}$ & + & 1 & + & + & . & $\mathrm{r}$ & + & + \\
\hline Cyclamen purpurascens & $\mathrm{C}$ & $\mathrm{r}$ & . & + & + & 2 & . & . & . \\
\hline Lathyrus vernus +venetus & $\mathrm{C}$ & + & . & $\mathrm{r}$ & + & . & 1 & + & + \\
\hline Peltaria alliacea & $\mathrm{C}$ & + & . & + & + & . & $\mathrm{r}$ & . & . \\
\hline Arum maculatum & $\mathrm{C}$ & $\mathrm{r}$ & . & . & . & + & . & . & + \\
\hline
\end{tabular}

Fagetalia

Corylus avellana

Corylus avellana

Euonymus europaeus 


\begin{tabular}{|c|c|c|c|c|c|c|c|c|c|}
\hline Relevé number & & 1 & 2 & 3 & 4 & 5 & 6 & 7 & 8 \\
\hline Dactylis glomerata & $\mathrm{C}$ & + & + & 1 & + & + & 2 & . & + \\
\hline Mercurialis perennis & $\mathrm{C}$ & + & 1 & $\mathrm{r}$ & + & + & . & . & . \\
\hline Lamium galeobdolon & $\mathrm{C}$ & + & + & + & + & . & . & + & . \\
\hline Veronica chamaedrys & $\mathrm{C}$ & $\mathrm{r}$ & . & $\mathrm{r}$ & . & + & $\mathrm{r}$ & . & + \\
\hline Galium sylvaticum & $\mathrm{C}$ & . & + & . & + & . & . & + & + \\
\hline Glechoma hirsuta & $\mathrm{C}$ & . & . & . & . & 1 & + & + & + \\
\hline Symphytum tuberosum & $\mathrm{C}$ & + & + & + & . & . & + & . & . \\
\hline Brachypodium sylvaticum & $\mathrm{C}$ & + & + & . & + & + & . & . & . \\
\hline Cardamine bulbifera & $\mathrm{C}$ & + & . & 1 & . & + & . & . & . \\
\hline Campanula trachelium & $\mathrm{C}$ & $\mathrm{r}$ & . & $\mathrm{r}$ & . & . & + & + & . \\
\hline Geum urbanum & $\mathrm{C}$ & . & . & . & $\mathrm{r}$ & + & + & . & + \\
\hline Galium schultesii & $\mathrm{C}$ & + & . & + & . & . & + & . & . \\
\hline Polygonatum multiflorum & $\mathrm{C}$ & + & + & + & . & . & . & . & . \\
\hline Asarum europaeum & $\mathrm{C}$ & + & + & . & . & . & $\mathrm{r}$ & . & . \\
\hline Silene dioica & $\mathrm{C}$ & + & . & 1 & . & . & . & . & + \\
\hline Galanthus nivalis & $\mathrm{C}$ & + & . & + & . & + & . & . & . \\
\hline Melica uniflora & $\mathrm{C}$ & + & . & . & + & . & . & . & 1 \\
\hline Ruscus hypoglossum & $\mathrm{B}$ & + & . & . & . & . & . & . & + \\
\hline Lactuca muralis & $\mathrm{C}$ & . & + & . & $\mathrm{r}$ & + & . & . & . \\
\hline Cardamine impatiens & $\mathrm{C}$ & $\mathrm{r}$ & . & $\mathrm{r}$ & . & . & . & . & + \\
\hline \multicolumn{10}{|l|}{ Quercetea pubescentis } \\
\hline Cornus mas & A & 1 & 3 & . & 1 & 1 & . & . & . \\
\hline Cornus mas & B & 1 & 1 & 2 & 2 & 2 & 2 & 2 & 2 \\
\hline Sesleria autumnalis & $\mathrm{C}$ & + & 1 & 1 & + & . & 2 & . & . \\
\hline Campanula persicifolia & $\mathrm{C}$ & + & . & $\mathrm{r}$ & . & . & + & . & . \\
\hline Potentilla micrantha & $\mathrm{C}$ & + & . & 1 & + & . & . & . & . \\
\hline \multicolumn{10}{|l|}{ Companions } \\
\hline Pseudoturritis turrita & $\mathrm{C}$ & + & . & $\cdot$ & . & + & + & . & . \\
\hline Valeriana officinalis & $\mathrm{C}$ & $\mathrm{r}$ & + & $\mathrm{r}$ & . & . & . & . & . \\
\hline Verbascum nigrum & $\mathrm{C}$ & $\mathrm{r}$ & . & $\mathrm{r}$ & $\mathrm{r}$ & . & . & . & . \\
\hline
\end{tabular}

In one or two relevés:

A: Staphylea pinnata 1: +, 2: 2; Crataegus monogyna 2: 1, 8: +; Corylus avellana 2: 1, 9: +; Acer obtusatum 5: 1, 9: 1; Carpinus betulus 5: 1, 9: +; Acer hyrcanum ssp. intermedium 2: 1; Tilia cordata 2: 1; Sorbus aria 3: 1; Tilia platyphyllos 7: 1; Acer campestre 7: 1; Ulmus glabra 5: 1; Ulmus minor 9: +;

B: Cotinus coggygria 2: 1, 6: +; Ostrya carpinifolia 6: +, 7: 2; Ruscus aculeatus 1: +, 6: 1; Acer campestre 1: r, 3: r; Crataegus monogyna 2: 1, 4: +; Acer monspessulanum 2: 1, 4: +; Viburnum lantana 2: +, 4: r; Ulmus minor 4: +, 7: +; Acer obtusatum 5: 2, 9: 1; Hippocrepis emerus ssp. emeroides 6: 1; Ligustrum vulgare 1: +; Rosa arvensis 1: +; Tilia cordata 2: +; Sorbus aria 3: +; Daphne laureola 5: 1; Lonicera xylosteum 7: +; Quercus robur 7: r; Clematis vitalba 8: +; Crataegus laevigata 9: +;

C:Viola hirta 1: +, 3: r; Hylotelephium maximum 4: +, 6: +; Moehringia trinervia 1: +, 3: +; Tamus communis 1: +, 6: r; Smyrnium perfoliatum 1: r, 6: +; Arabidopsis arenosa 4: +, 8: +; Poa angustifolia 6: +, 8: +; Fragaria moschata 6: r; Stellaria holostea 1: +; Carex sylvatica 1: +; Primula acaulis 1: +; Alliaria petiolata 1: +; Epimedium alpinum 2: 1; Clematis recta 2: +; Convallaria majalis 2: +; Laserpitium krapfii ssp. krapfii 2: +; Asplenium ruta-muraria 2: +; Euphorbia amygdaloides 2: +; Vincetoxicum hirundinaria 2: +; Symphyandra hofmannii 2: r; Lilium martagon 2: r; Tanacetum corymbosum 2: r; Urtica dioica 2: r; Adoxa moschatellina 3: r; Pulmonaria officinalis 4: +; Scutellaria altissima 4: r; Carex divulsa ssp. leersii 5: +; Galium lucidum 5: +; Arum italicum 5: +; Poa nemoralis 5: +; Anemone ranunculoides 5: +; Cardamine hirsuta 5: r; Galium aparine 5: r; Digitalis grandiflora 6: +; Cruciata glabra 6: +; Isopyrum thalictroides 6: +; Geranium lucidum 6: r; Lunaria rediviva 7: +; Viola reichenbachiana 7: +; Inula conyza 7: +; Parietaria officinalis 7: +; Pseudofumaria alba ssp. leiosperma 8: +.

Details of relevés (indicated in the following order: relevé number, GIVD EU-BA-001 relevé number, date (year/ month/day), description of locality, longitude, latitude):

1) 2936, 2015/05/14, Ispod Greben grada (Krupa na Vrbasu), 17.13748, 44.61054; 2) 3109, 2018/06/21, Kanjon Crne rijeke (desna obala), 17.165446, 44.463635; 3) 2935, 2015/05/14, Ispod Greben grada (Krupa na Vrbasu), 17.137663, 44.610092; 4) 3102, 2018/06/20, Kanjon Vrbasa (desna obala, Tijesno), 17.197794, 44.68809; 5) 3646, 2020/04/15, Čelinski potok (Starčevica), 17.267045, 44.726266; 6) 2933, 2015/05/14, Ispod Greben grada (Krupa na Vrbasu), 17.137304, 44.609612; 7) 3613, 2018/06/20, Kanjon Vrbasa (desna obala, Tijesno), 17.197921, 44.687727; 8) 3610, 2018/06/20, Kanjon Vrbasa (desna obala, Tijesno), 17.19911, 44.68801. 